\title{
Ecological Risks and Spatial Distributions of Heavy Metals in Beijing Atmospheric Dust
}

\author{
Dejun Wan ${ }^{1 *}$, Guanglin Yang ${ }^{1}$, Jinsong Yang ${ }^{1}$, Changlin Zhan ${ }^{2}$ \\ ${ }^{1}$ Institute of Hydrogeology and Environmental Geology, Chinese Academy of Geological Sciences, \\ Shijiazhuang 050061, China \\ ${ }^{2}$ School of Environmental Science and Engineering, Hubei Polytechnic University, \\ Huangshi 435003, China
}

Received: 6 June 2017

Accepted: 9 August 2017

\begin{abstract}
To investigate ecological risks and spatial distributions of heavy metals in atmospheric particles in the Beijing urban area, atmospheric dust was collected from 62 sites and 12 heavy metals in their $<63 \mu \mathrm{m}$ fractions were measured. Results indicate that $\mathrm{V}, \mathrm{Cr}, \mathrm{Mn}, \mathrm{Co}, \mathrm{Ni}$, and $\mathrm{Ba}$ in the dust are basically unpolluted by human activities; whereas $\mathrm{Cu}, \mathrm{Zn}, \mathrm{As}, \mathrm{Cd}, \mathrm{Sb}$, and $\mathrm{Pb}$ are moderately to heavily polluted. These metals (not including $\mathrm{Ba}$ ) in most dust show a high ecological risk ( $\mathrm{RI}=809 \pm 585$, ranging 291-4,848), predominantly contributed by $\mathrm{Cd}(71 \%)$ and $\mathrm{Sb}$ (14\%). Relatively higher risks mainly occur in the eastern and northwestern urban areas. The high risks in the east are caused mainly by Cd pollution associated with coal-burning and industrial and traffic activities, while those in the northwest are caused mainly by $\mathrm{Sb}$ pollution associated with point pollution sources and $\mathrm{Cd}$ pollution from traffic activity. This is significant for controlling atmospheric heavy metal pollution over the Beijing urban area and investigating atmospheric metal pollution in other cities.
\end{abstract}

Keywords: atmospheric particulate pollution, heavy metal, geo-accumulation index, ecological risk, spatial distribution, source

\section{Introduction}

Owing to the rapid development of industrialization and urbanization over the past several decades in China, atmospheric particulate pollution has become more and more serious in large cities, posing great risks to urban ecosystems and human health [1-3]. As an important component in urban ecosystems, atmospheric particles not only pose risks to biological components such as human beings, animals, and plants, etc., but also influence

*e-mail: dejunwan@foxmail.com the quality of water, soil, and sediment after being deposited onto the earth's surface [4-5]. Generally, risks of the atmospheric particulate pollution to ecosystems and human beings are largely caused by toxic pollutants adhering to particles. Among pollutants, heavy metals, which are hard to metabolize in a living body and do harm to circulatory and central and peripheral nervous systems [6-7], constitute one of the most important types in various environmental media.

Beijing, located northwest of the North China Plain, is one of the most seriously polluted cities for atmospheric particles in China [8-10]. It is not only the nation's capital, but also is one of the most densely populated cities in China, 
so investigating heavy metal pollution in atmospheric particles in the city is significant for protecting the urban ecosystem and human health and improving China's image. In fact, in recent years the heavy metal pollution of atmospheric particles in Beijing has aroused great attention, and a lot of valuable work has been done to investigate their concentrations, pollution levels, sources, temporal variations, controlling measures, and so on [8, 10-15]. However, until now few studies have examined the detailed spatial distributions and ecological risks of the heavy metals in atmospheric particles based on highspatial-resolution sampling over the Beijing urban area due to the relatively heavy workload of the traditional filter membrane sampling method.

Under calm or weak wind conditions, atmospheric particles can gradually be deposited onto the ground and other object surfaces. At locations seldom disturbed by wind, rain, and human activities, the settled particles can accumulate as what is called atmospheric dust (fall). Generally, the atmospheric dust can maintain most physicochemical characteristics of atmospheric particles and thus are often used to investigate regional atmospheric particulate pollution, for it is relatively easier to be collected [7, 15-17]. In this study atmospheric dust samples were collected from 62 sites in the Beijing urban area, and 12 heavy metals were detected in their $<63 \mu \mathrm{m}$ fractions. The objects of this study are to:

1) Assess pollution levels and ecological risks of these heavy metals in atmospheric particles in the Beijing urban area.

2) Reveal spatial distributions of the risks.

3) Identity areas and metals with the highest risks and determine their main polluting sources.

The study is significant for not only establishing reasonable measures for air-quality management in the Beijing urban area, but also understanding atmospheric particulate pollution in other cities in China.

\section{Experimental}

\section{Sampling and Analysis}

Atmospheric dust samples were collected from 62 sub-areas over the Beijing main urban area in spring 2015 (Fig. 1). To obtain dust samples with certain regional representativeness, relatively large residential quarters that are relatively far away from obviously polluting sources were usually chosen for dust sampling. Generally, dust was collected mainly from uncleaned windowsills, flat roofs, and surfaces of pipeline installed on buildings that are seldom disturbed by wind, rain, and human activities and usually more than five meters above the ground. At each sampling site dust was collected from several subsites using a small brush or a dry-type vacuum cleaner and these sub-samples were mixed as one at last [15].

After being taken back to the laboratory, $<63$ $\mu \mathrm{m}$ fraction of each dust was isolated by passing a 250 mesh $(\sim 63 \mu \mathrm{m})$ sieve and only this faction was used

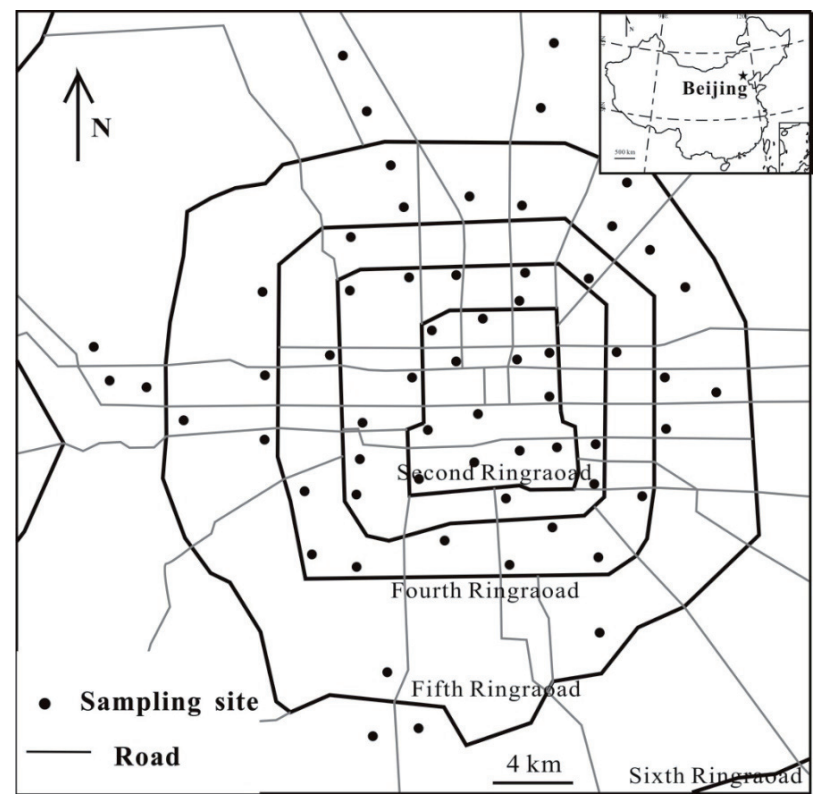

Fig. 1. Sixty-two sampling sites for atmospheric dust in the Beijing urban area.

for heavy metal analysis $[15,18]$. After being fully dried in an oven, about $0.125 \mathrm{~g}$ dust was weighed and hotdigested with concentrated $\mathrm{HNO}_{3}, \mathrm{HClO}_{4}, \mathrm{HF}$, and $\mathrm{HCl}$ in a Teflon beaker on a hot plate. Concentrations of $\mathrm{Co}$, $\mathrm{Ni}, \mathrm{Cu}, \mathrm{As}, \mathrm{Cd}, \mathrm{Sb}$, and $\mathrm{Pb}$ in dust were determined by an Agilent 7,700x inductively coupled plasma mass spectrometry (ICP-MS) and V, Cr, Mn, Zn, and Ba by a Leeman Labs Profile inductively coupled plasma atomic emission spectrometry (ICP-AES). Procedural blanks, standard reference material (GBW07309), and duplicates for every ten-sample were used to control the quality of these measurements. The determined concentrations of these elements in the blanks were $<1 \%$ of the average corresponding element values. The detected concentrations of these elements in the reference material were about $100 \pm 8 \%$ of the standard values.

\section{Geo-Accumulation Index}

Geo-accumulation index $\left(\mathrm{I}_{\text {geo }}\right)$ of heavy metals is calculated by [19]:

$$
\mathrm{I}_{\text {geo }}=\log _{2}\left[\mathrm{X}_{\mathrm{i}} /\left(1.5 \mathrm{X}_{\mathrm{ib}}\right)\right]
$$

...where $X_{i}$ represents the concentration of metal $i$ in atmospheric dust and $\mathrm{X}_{\mathrm{ib}}$ is that in the local (Beijing) natural soil [20-21].

According to Müller [19], the $\mathrm{I}_{\text {geo }}$ indexes can be divided into seven classes as follows: 1 ) $\mathrm{I}_{\text {geo }} \leq 0$, practically unpolluted; 2) $0<\mathrm{I}_{\text {geo }} \leq 1$, slightly polluted; 3) $1<\mathrm{I}_{\text {geo }} \leq 2$, moderately polluted; 4) $2<\mathrm{I}_{\text {geo }} \leq 3$, moderately to heavily polluted; 5) $3<\mathrm{I}_{\text {geo }} \leq 4$, heavily polluted; 6) $4<\mathrm{I}_{\text {geo }} \leq 5$, heavily to extremely polluted; and 7) $\mathrm{I}_{\text {geo }}>5$, extremely polluted. 


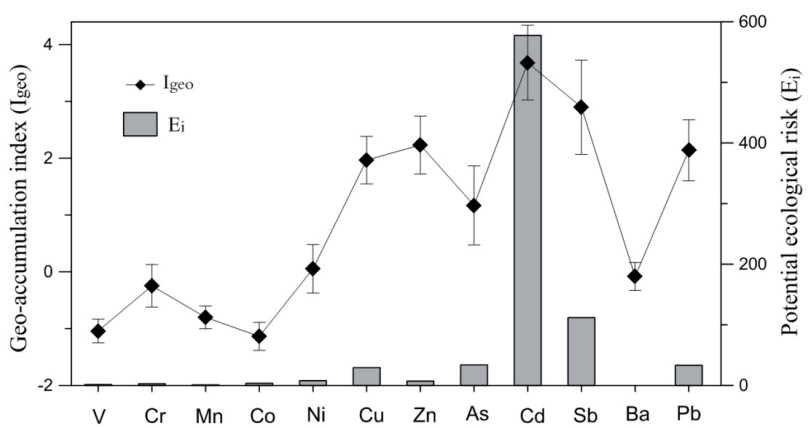

Fig. 2. Geo-accumulation indexes $\left(\mathrm{I}_{\mathrm{gee}}\right)$ and potential ecological risks $\left(\mathrm{E}_{\mathrm{i}}\right.$ ) (not including $\mathrm{Ba}$ ) of heavy metals in the $<63 \mu \mathrm{m}$ fractions of the 62 atmospheric dust.

\section{Potential Ecological Risk Assessment}

Potential ecological risks are assessed by the following equations [22]:

$$
\begin{aligned}
& \mathrm{E}_{\mathrm{i}}=\mathrm{T}_{\mathrm{i}} \times \frac{\mathrm{C}_{\mathrm{s}}^{\mathrm{i}}}{\mathrm{C}_{\mathrm{b}}^{\mathrm{i}}} \\
& \mathrm{RI}=\sum \mathrm{E}_{\mathrm{i}}
\end{aligned}
$$

...where $\mathrm{E}_{\mathrm{i}}$, the potential ecological risk of metal $\mathrm{i}$ in the dust; $\mathrm{T}_{\mathrm{i}}(\mathrm{Cd}=30, \mathrm{As}=\mathrm{Sb}=10, \mathrm{Co}=\mathrm{Ni}=\mathrm{Cu}=\mathrm{Pb}=5$, $\mathrm{V}=\mathrm{Cr}=2, \mathrm{Mn}=\mathrm{Zn}=1)[15,22-24]$, the toxic-response factor of metal $\mathrm{i} ; \mathrm{C}_{\mathrm{s}}^{\mathrm{i}}$, the concentration of metal $\mathrm{i}$ in dust; $\mathrm{C}_{\mathrm{b}}^{\mathrm{i}}$, the background value of metal $\mathrm{i}$ in the Beijing natural soil [20-21]; and RI, the potential ecological risk of all the measured metals in the dust.

The ecological risk levels can be divided into five classes $[22,25]: \mathrm{E}_{\mathrm{i}}<40, \mathrm{RI}<150$, low ecological risk; $40 \leq \mathrm{E}_{\mathrm{i}}<80,150 \leq \mathrm{RI}<300$, moderate ecological risk; $80 \leq \mathrm{E}_{\mathrm{i}}<160,300 \leq \mathrm{RI}<600$, considerable ecological risk; $160 \leq \mathrm{E}_{\mathrm{i}}<320,600 \leq \mathrm{RI}<1,200$, high ecological risk; and $\mathrm{E}_{\mathrm{i}} \geq 320, \mathrm{RI} \geq 1,200$, very high ecological risk.

\section{Results and Discussion}

\section{Levels of Heavy Metals in Atmospheric Dust}

Concentrations of the 12 heavy metals in the $<63 \mu \mathrm{m}$ fractions of the 62 atmospheric dusts from the Beijing urban area are shown in Table 1. The mean concentrations of $\mathrm{V}, \mathrm{Cr}, \mathrm{Mn}, \mathrm{Co}, \mathrm{Ni}, \mathrm{Cu}, \mathrm{Zn}, \mathrm{As}, \mathrm{Cd}, \mathrm{Sb}, \mathrm{Ba}$, and $\mathrm{Pb}$ in the dust are $0.7,1.3,0.9,0.7,1.6,5.9,7.0,3.4,19.2,11.2$, 1.4, and 6.6 times that of the local (Beijing) natural soil, respectively [20-21]. The pollution levels of these 12 metals decrease in the following order according to their $\mathrm{I}_{\text {geo }}$ values in Fig. 2: $\mathrm{Cd}=$ heavily polluted $>\mathrm{Sb}>\mathrm{Zn}>$ $\mathrm{Pb}=$ moderately to heavily polluted $>\mathrm{Cu}>\mathrm{As}=$ moderately polluted $>\mathrm{Ni}=$ slightly polluted $>\mathrm{Ba}>\mathrm{Cr}>$ $\mathrm{Mn}>\mathrm{V}>\mathrm{Co}=$ practically unpolluted.

Among the twelve heavy metals, the mean concentrations of $\mathrm{V}, \mathrm{Cr}, \mathrm{Mn}, \mathrm{Co}, \mathrm{Ni}$, and $\mathrm{Ba}$ are basically

Table 1. Statistical results for concentrations of heavy metals in the $<63 \mu \mathrm{m}$ fractions of the 62 atmospheric dusts from the Beijing urban

\begin{tabular}{|c|c|c|c|c|c|c|c|c|c|c|c|c|}
\hline Metal & $\begin{array}{c}\mathrm{Min} \\
\mathrm{mg} / \mathrm{kg}\end{array}$ & $\begin{array}{c}\mathrm{Max} \\
\mathrm{mg} / \mathrm{kg}\end{array}$ & $\begin{array}{l}\text { Mean } \\
\mathrm{mg} / \mathrm{kg}\end{array}$ & Stdev & $\begin{array}{c}\text { Soil } \\
\mathrm{mg} / \mathrm{kg}\end{array}$ & $\begin{array}{c}\text { Changchun } \\
\mathrm{mg} / \mathrm{kg}\end{array}$ & $\begin{array}{l}\text { Xi'an } \\
\mathrm{mg} / \mathrm{kg}\end{array}$ & $\begin{array}{l}\text { Wuhan } \\
\mathrm{mg} / \mathrm{kg}\end{array}$ & $\begin{array}{c}\text { Shanghai } \\
\mathrm{mg} / \mathrm{kg}\end{array}$ & $\begin{array}{c}\text { Changsha } \\
\mathrm{mg} / \mathrm{kg}\end{array}$ & $\begin{array}{c}\text { Guangzhou } \\
\mathrm{mg} / \mathrm{kg}\end{array}$ & $\begin{array}{c}\text { Hongkong } \\
\mathrm{mg} / \mathrm{kg}\end{array}$ \\
\hline V & 36.0 & 73.0 & 57.9 & 7.9 & 79.2 & & 84.8 & & 59.6 & & & 25.5 \\
\hline $\mathrm{Cr}$ & 45.0 & 179.0 & 86.0 & 24.8 & 68.1 & 96 & & 130 & 242 & 403.5 & 176.2 & 324 \\
\hline $\mathrm{Mn}$ & 373.0 & 796.0 & 607.1 & 79.4 & 705.0 & 692 & 581 & & 904 & & 539.8 & 639 \\
\hline Co & 6.3 & 16.9 & 10.6 & 1.8 & 15.6 & & 19.4 & 14 & 12.1 & & & 10.2 \\
\hline $\mathrm{Ni}$ & 24.0 & 109.0 & 45.2 & 16.1 & 29.0 & & 56.7 & 33 & & & 41.4 & \\
\hline $\mathrm{Cu}$ & 84.0 & 356.0 & 138.4 & 49.6 & 23.6 & 68.4 & 102.7 & 138 & 141 & 126 & 192.4 & 534 \\
\hline $\mathrm{Zn}$ & 382.0 & $2,156.0$ & 722.7 & 335.5 & 102.6 & 465.4 & 798 & 835 & 699 & 1,542 & $1,777.2$ & 4,024 \\
\hline As & 9.0 & 180.0 & 23.9 & 24.3 & 7.1 & 23.3 & 28.5 & & & & 20.1 & \\
\hline $\mathrm{Cd}$ & 0.9 & 18.8 & 2.29 & 2.3 & 0.119 & 0.624 & & 1.6 & 0.9 & 2.5 & 2.14 & 1.8 \\
\hline $\mathrm{Sb}$ & 4.0 & 110.1 & 12.3 & 14.9 & 1.1 & & & & & & 14.8 & \\
\hline $\mathrm{Ba}$ & 535.0 & $1,054.0$ & 752.3 & 131.1 & 531 & & 916 & & & & & \\
\hline $\mathrm{Pb}$ & 71.0 & 396.0 & 167.9 & 68.2 & 25.4 & 93.6 & 266.3 & 281 & 148 & 348 & 387.5 & 240 \\
\hline $\begin{array}{c}\text { Data } \\
\text { Source }\end{array}$ & $\begin{array}{l}\text { This } \\
\text { study }\end{array}$ & $\begin{array}{l}\text { This } \\
\text { study }\end{array}$ & $\begin{array}{l}\text { This } \\
\text { study }\end{array}$ & $\begin{array}{c}\text { This } \\
\text { study }\end{array}$ & a & [26] & [27] & [28] & [29] & [30] & [31] & [29] \\
\hline
\end{tabular}
area. In addition, mean concentrations of these metals in the Beijing natural soil and in dust from other typical cities in China.

${ }^{\text {a }}$ Data of $\mathrm{V}, \mathrm{Cr}, \mathrm{Mn}, \mathrm{Co}, \mathrm{Ni}, \mathrm{Cu}, \mathrm{Zn}, \mathrm{Sb}, \mathrm{Ba}$, and $\mathrm{Pb}$ in the local (Beijing) natural soil are from CNEMC [20], and As and $\mathrm{Cd}$ from Chen et al. [21]. 
close to that of their corresponding values in the Beijing natural soil [20-21] (Table 1), respectively. And their $I_{\text {geo }}$ values are generally below or close to zero (Fig. 2), indicating no or slight pollution of these six metals in the atmospheric dust. This fact suggests that these six metals in the Beijing atmospheric dust are derived predominantly from natural sources and not or only slightly affected by human activities.

In contrast, the mean concentrations of the other six metals of $\mathrm{Cu}, \mathrm{Zn}, \mathrm{As}, \mathrm{Cd}, \mathrm{Sb}$, and $\mathrm{Pb}$ in the atmospheric dust are often obviously (3.4-19.2 times) higher than that of their corresponding values in the Beijing natural soil [20-21] (Table 1). Besides, the $\mathrm{I}_{\text {geo }}$ values of $\mathrm{Cu}, \mathrm{Zn}, \mathrm{As}, \mathrm{Cd}$, $\mathrm{Sb}$, and $\mathrm{Pb}$ are relatively higher, which are 2.0, 2.2, 1.2, 3.7, 2.9, and 2.1, respectively (Fig. 2), indicating moderate to heavy pollution levels of these six metals. This fact suggests that these six heavy metals in the atmospheric dust are often significantly affected by human activities and derived mainly from anthropogenic sources.

Compared with dust from other typical cities in China (Table 1), the mean concentrations of most heavy metals in the Beijing dust are higher than that from Changchun [26] and roughly close to that from Xi'an [27], Wuhan [28], and Shanghai [29], but obviously lower than those from Changsha [30], Guangzhou [31], and Hong Kong [29]. This comparison suggests a relatively lower pollution level of heavy metals in the dust from Beijing among typically large cities in China, despite human activities being more intensive and economies more developed in Beijing compared with most other cities in China. The relatively low pollution levels of most heavy metals in the Beijing dust may be due to that as the capital of China the Beijing government has taken many effective measures in recent years to control environmental pollution, such as shutting down or relocating heavily polluting units to suburban areas or surrounding satellite cities, improving energy-consuming structure, etc.

\section{Ecological Risks of Heavy Metals in Atmospheric Dust}

From the potential ecological risk assessment results in Fig. 2, it can be seen that the mean $E_{i}$ values of these 11 metals (not including $\mathrm{Ba}$ ) in atmospheric dust decrease in the order of $\mathrm{Cd}=577>\mathrm{Sb}=112>40>\mathrm{As}>\mathrm{Pb}>\mathrm{Cu}$ $>\mathrm{Ni}>\mathrm{Zn}>\mathrm{Co}>\mathrm{Cr}>\mathrm{V}>\mathrm{Mn}$. Among the 11 heavy metals, $\mathrm{Cd}$ is of the highest $\mathrm{E}_{\mathrm{i}}$ values with an average of 577, suggesting a very high ecological risk level. The second highest $\mathrm{E}_{\mathrm{i}}$ is $\mathrm{Sb}$, which averages 112, suggesting a considerable ecological risk level. The $E_{i}$ values of these two metals, which are strikingly higher than that of the others, account for $85 \%$ of the total ecological risk of the 11 heavy metals in atmospheric dust. The mean $\mathrm{E}_{\mathrm{i}}$ values of $\mathrm{As}, \mathrm{Pb}$, and $\mathrm{Cu}$ are 29-34, suggesting a low ecological risk level of these three metals. These three metals contribute $12 \%$ of the total ecological risk. For the other six metals ( $\mathrm{V}, \mathrm{Cr}, \mathrm{Mn}, \mathrm{Co}, \mathrm{Ni}$, and $\mathrm{Zn}$ ), their mean $\mathrm{E}_{\mathrm{i}}$ values are all below 10 , indicating negligible ecological risks of these metals in the dust.
Compared with the pollution levels of these metals (Fig. 2), it can be found that $\mathrm{Cd}$ and $\mathrm{Sb}$, which are of high pollution levels, show high ecological risks, while $\mathrm{V}, \mathrm{Cr}$, $\mathrm{Mn}, \mathrm{Co}$, and $\mathrm{Ni}$, which are of low pollution levels, show negligible ecological risks. However, $\mathrm{Cu}, \mathrm{Zn}$, and $\mathrm{Pb}$ are also of relatively high pollution levels, but they show low ecological risks, which is caused by obviously lower toxicresponse factors of these three metals compared with $\mathrm{Cd}$ and $\mathrm{Sb}$. This fact suggests the importance of ecological risk assessment for finding out the most threatening elements in environmental media.

The total ecological risks (RIs) of these 11 metals

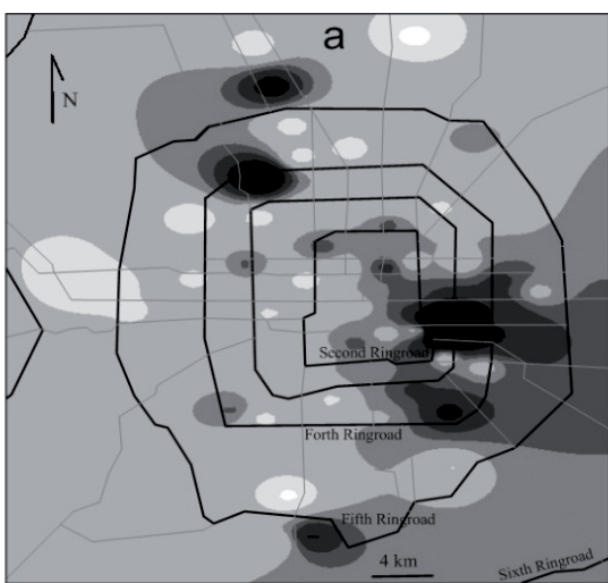

$\mathrm{RI}$
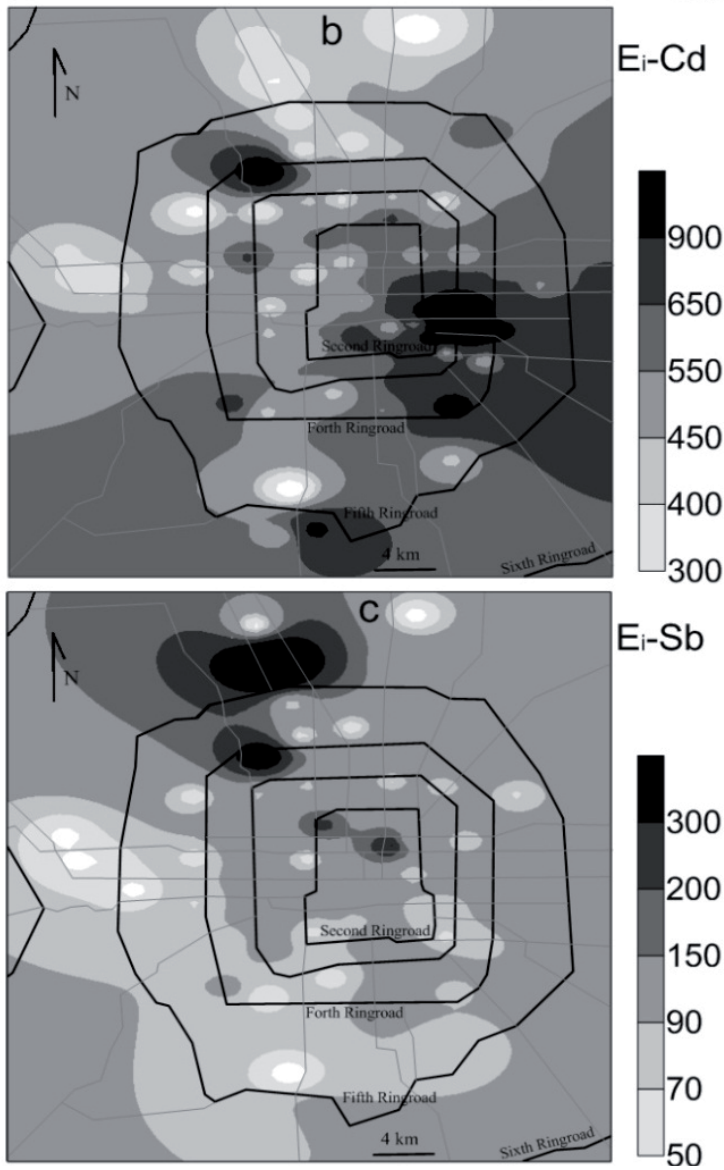

300

150

90

Fig. 3. Spatial distributions of potential ecological risks of heavy metals in atmospheric dust. 
Table 2. Pearson's correlation matrix for concentrations of heavy metals in atmospheric dust.

\begin{tabular}{|c|c|c|c|c|c|c|c|c|c|c|c|c|}
\hline & $\mathrm{V}$ & $\mathrm{Cr}$ & $\mathrm{Mn}$ & $\mathrm{Co}$ & $\mathrm{Ni}$ & $\mathrm{Cu}$ & $\mathrm{Zn}$ & $\mathrm{As}$ & $\mathrm{Cd}$ & $\mathrm{Sb}$ & $\mathrm{Ba}$ & $\mathrm{Pb}$ \\
\hline $\mathrm{V}$ & & 0 & 0 & 0 & 0.009 & 0.500 & 0.119 & 0.804 & 0.879 & 0.102 & 0.923 & 0.260 \\
\hline $\mathrm{Cr}$ & $0.467^{* *}$ & & 0 & 0.106 & 0.025 & 0.015 & 0.500 & 0.752 & 0.438 & 0.886 & 0.291 & 0.215 \\
\hline $\mathrm{Mn}$ & $0.699^{* *}$ & $0.457^{* *}$ & & 0.001 & 0.054 & 0.785 & 0.206 & 0.987 & 0.478 & 0.539 & 0.967 & 0.845 \\
\hline $\mathrm{Co}$ & $0.599^{* *}$ & 0.207 & $0.419^{* *}$ & & 0.509 & 0.366 & 0.031 & 0.035 & 0.140 & 0.111 & 0.371 & 0.050 \\
\hline $\mathrm{Ni}$ & $0.327^{* *}$ & $0.284^{*}$ & 0.246 & 0.086 & & 0.010 & 0.671 & 0.018 & 0.849 & 0.863 & 0.467 & 0.593 \\
\hline $\mathrm{Cu}$ & 0.087 & $0.306^{*}$ & 0.035 & 0.117 & $0.325^{* *}$ & & 0.068 & 0.577 & 0.516 & 0.837 & 0.588 & 0.001 \\
\hline $\mathrm{Zn}$ & 0.200 & 0.087 & 0.163 & $0.274^{*}$ & 0.055 & 0.233 & & 0.831 & 0.923 & 0.856 & 0.028 & 0.095 \\
\hline $\mathrm{As}$ & 0.033 & 0.041 & -0.002 & $0.271^{*}$ & $0.303^{*}$ & 0.073 & 0.028 & & 0.586 & 0.831 & 0.970 & 0.674 \\
\hline $\mathrm{Cd}$ & 0.020 & 0.100 & 0.092 & 0.190 & -0.025 & 0.084 & 0.013 & 0.071 & & 0.648 & 0.945 & 0.123 \\
\hline $\mathrm{Sb}$ & 0.210 & 0.019 & 0.080 & 0.204 & 0.022 & 0.027 & 0.024 & 0.028 & 0.059 & & 0.231 & 0.001 \\
\hline $\mathrm{Ba}$ & 0.013 & -0.136 & -0.005 & 0.116 & -0.094 & -0.070 & $0.280^{*}$ & -0.005 & 0.009 & -0.154 & & 0.495 \\
\hline $\mathrm{Pb}$ & 0.145 & 0.160 & 0.025 & 0.250 & 0.069 & $0.420^{* *}$ & 0.214 & 0.055 & 0.198 & $0.414^{* *}$ & -0.088 & \\
\hline
\end{tabular}

The left lower part is correlation coefficient; the right upper part is significant level.

$* * P<0.01$ (two-tailed); $* P<0.05$ (two-tailed)

(not including $\mathrm{Ba}$ ) are between 291 and 4,848, with an average of $809 \pm 585$, suggesting a high ecological risk level of these heavy metals in atmospheric dust from the Beijing urban area. However, it should be noted that the above ecological risk results do not include other toxic elements (such as $\mathrm{Hg}$ ), for they were not measured in this study. If considering these unmeasured toxic elements, the ecological risk of heavy metals in Beijing atmospheric dust must be higher. Even so, the above results are enough to suggest that the heavy metal pollution in the atmospheric dust poses great risks to the urban ecosystem in Beijing, and thus should be controlled as soon as possible - especially for $\mathrm{Cd}$ and $\mathrm{Sb}$.

\section{Spatial Distributions of Ecological Risks of Heavy Metals in Atmospheric Dust}

Spatial distributions of the RIs of the 11 heavy metals in the atmospheric dust and that of $\mathrm{Cd}$ and $\mathrm{Sb}$, which are of the highest $\mathrm{E}_{\mathrm{i}}$ values, are shown in Fig. 3, which shows that relatively lower RIs of these heavy metals occur mainly in the western and northeastern urban areas in Beijing, while relatively higher RIs mainly occur in the eastern and the northwestern urban areas (Fig. 3a). The spatial distribution pattern is approximately similar to that of $\mathrm{Cd}$ (Fig. 3b), which is due to the dominant (71\%) contribution of $\mathrm{Cd}$ to the $\mathrm{RI}$.

Correlation analysis results suggest that $\mathrm{Cd}$ has no correlation with all the other metals (Table 2), implying that $\mathrm{Cd}$ pollution in atmospheric dust is likely affected by multiple polluting sources. Previous studies involving source apportionment of heavy metals in atmospheric particles from the Beijing urban area suggest different major sources of $\mathrm{Cd}$, which may be due to the atmospheric particles being collected from different areas and during different periods [8, 10, 12-13]. However, all of these studies indicate that the $\mathrm{Cd}$ pollution in atmospheric particles is usually associated with coal-burning, traffic, and industrial emissions. Based on the distribution of human activities (pollution emissions) in different Beijing urban areas, it can be further found that the highest RIs of $\mathrm{Cd}$ at the east second, third, and fourth ring roads are likely a consequence of relatively more coal-burning emissions [32] and traffic activities; the relatively higher $\mathrm{RIs}$ of $\mathrm{Cd}$ in the other eastern urban areas are likely associated with relatively more industrial activities [33] and coal-burning emissions [34]; and the relatively higher $\mathrm{RI}$ of $\mathrm{Cd}$ in the northwest Fourth Ring Road is probably due to relatively more traffic activities in this area. This information is significant for controlling heavy metal pollution in atmospheric particles in the Beijing urban area.

Among these 11 metals, the $\mathrm{E}_{\mathrm{i}}$ of $\mathrm{Sb}$, which contributes $14 \%$ of total ecological risk, is the second highest. From Fig. 3c) we can find that relatively lower RIs of Sb occur mainly in the western and southern urban areas, while relatively higher risks mainly occur in the northwestern urban area. Our previous study suggests that the enrichment of $\mathrm{Sb}$ in atmospheric dust is mainly associated with traffic-related emissions over the entire Beijing urban area [15]. Gao et al. [13] evaluates sources of toxic elements in total suspended particulates from the Beijing urban area and also finds the major contribution of vehicle emissions to $\mathrm{Sb}$. However, the extremely higher RIs of $\mathrm{Sb}$ at the outside of the north Fourth Ring Road (Fig. 3c) may be associated with other point pollution sources such as waste incineration emissions, as suggested by Zhang et al. [8], for the traffic activities are moderate in this area. With respect to the other elements of $\mathrm{V}, \mathrm{Cr}, \mathrm{Mn}, \mathrm{Co}, \mathrm{Ni}, \mathrm{Cu}, \mathrm{Zn}, \mathrm{As}$, and $\mathrm{Pb}$, they all show 
low ecological risks and contribute no more than $15 \%$ of the total ecological risks, so their spatial patterns are not discussed in this study.

\section{Conclusions}

This study presents heavy metal results in the $<63 \mu \mathrm{m}$ fraction of atmospheric dust collected from 62 sites over the Beijing urban area. The results of 12 representative heavy metals suggest that $\mathrm{V}, \mathrm{Cr}, \mathrm{Mn}, \mathrm{Co}, \mathrm{Ni}$, and $\mathrm{Ba}$ in the atmospheric dust show unpolluted or slightly polluted levels, indicating natural sources; whereas $\mathrm{Cu}, \mathrm{Zn}$, As, $\mathrm{Cd}, \mathrm{Sb}$, and $\mathrm{Pb}$ show moderately to heavily polluted levels, implying anthropogenic origins. The total ecological risks of these metals (not including $\mathrm{Ba}$ ) in the atmospheric dust average $809 \pm 585$, ranging from 291 to 4,848, suggesting high ecological risks of most dust samples. The risk levels of these metals in the dust decrease in the order of $577=\mathrm{Cd}=$ very high ecological risk $>112=\mathrm{Sb}=$ considerable ecological risk $>$ low ecological risk $=$ As $>\mathrm{Pb}>\mathrm{Cu}>\mathrm{Ni}>\mathrm{Zn}>\mathrm{Co}>\mathrm{Cr}>\mathrm{V}>\mathrm{Mn}$. Relatively higher risks mainly occur in the eastern and northwestern urban areas. The high risks in the east are mainly caused by $\mathrm{Cd}$ pollution associated with coal-burning and industrial and traffic activities, while those in the northwest are mainly caused by $\mathrm{Sb}$ pollution associated with point pollution sources and $\mathrm{Cd}$ pollution with traffic activities. These results suggest that the heavy metal pollution in atmospheric particles poses great risks to the urban ecosystem of Beijing, and thus it should be controlled as soon as possible, especially for $\mathrm{Cd}$ in the eastern area.

\section{Acknowledgements}

This work was funded by a project supported by the Beijing Postdoctoral Research Foundation (011145402701). We thank Prof. Zhangdong Jin and Dr. Fei Zhang for their assistance with sample preparations and laboratory analyses.

\section{References}

1. CAO J. $\mathrm{PM}_{25}$ and the Environment in China, Beijing Science Press: Beijing, China, 2014 [In Chinese].

2. HUANG R., ZHANG Y., BOZZETTI C., HO K., CAO J., HAN Y., DAELLENBACH K.R, SLOWIK J.G., PLATT S.M., CANONACO F., ZOTTER P., WOLF R., PIEBER S.M., BRUNS E.A., CRIPPA M., CIARELLI G., PIAZZALUNGA A., SCHWIKOWSKI M., ABBASZADE G., SCHNELLE-KREIS J., ZIMMERMANN R., AN Z., SZIDAT S., BALTENSPERGER U., HADDAD I.E., PRÉVÔT A.S.H. High secondary aerosol contribution to particulate pollution during haze events in China. Nature, 514, 218, 2014.

3. LELIEVELD J., EVANS J.S., FNAIS M., GIANNADAKI D., POZZER A. The contribution of outdoor air pollution sources to premature mortality on a global scale. Nature, 525, 367, 2015.

4. GRANTZ D.A., GARNER J.H.B., JOHNSON D.W. Ecological effects of particulate matter. Environment International, 29 (2), 213, 2003.

5. ZHAI Y., LIU X., CHEN H., XU B., ZHU L., LI C., ZENG G. Source identification and potential ecological risk assessment of heavy metals in PM 2.5 from Changsha. Science of the Total Environment, 493, 109, 2014.

6. CHAPMAN P.M., WANG F., JANSSEN C.R., GOULET R.R., KAMUNDE C.N. Conducting ecological risk assessments of inorganic metals and metalloids: current status. Human and Ecological Risk Assessment, 9 (4), 641, 2003.

7. LEUNG A.O., DUZGOREN-AYDIN N.S., CHEUNG K.C., WON, M.H. Heavy metals concentrations of surface dust from e-waste recycling and its human health implications in southeast China. Environmental Science and Technology, 42 (7), 2674, 2008.

8. ZHANG R., JING J., TAO J., HSU S.C., WANG G., CAO J., LEE C.S.L., ZHU L., CHEN Z., ZHAO Y., SHEN Z. Chemical characterization and source apportionment of $\mathrm{PM}_{25}$ in Beijing: seasonal perspective. Atmospheric Chemistry and Physics, 13 (14), 7053, 2013.

9. BEPB (Beijing Environmental Protection Bureau). Report on Beijing environment state in 2014. 2015 [In Chinese].

10. PAN Y., TIAN S., LI X., SUN Y., LI Y., WENTWORTH G.R., WANG Y. Trace elements in particulate matter from metropolitan regions of Northern China: Sources, concentrations and size distributions. Science of the Total Environment, 537, 9, 2015.

11. HE K., YANG F., MA Y., ZHANG Q., YAO X., CHAN C., CADLE S., CHAN T., MULAWA P. The characteristics of $\mathrm{PM}_{2.5}$ in Beijing, China. Atmospheric Environment, 35 (29), 4959, 2001.

12. HAN L., ZHUANG G., CHENG S., WANG Y., LI J. Characteristics of re-suspended road dust and its impact on the atmospheric environment in Beijing. Atmospheric Environment, 41 (35), 7485, 2007.

13. GAO J., TIAN H., CHENG K., LU L., WANG Y., WU Y., ZHU C., LIU K., ZHOU J., LIU X., CHEN J., HAO J. Seasonal and spatial variation of trace elements in multi-size airborne particulate matters of Beijing China: Mass concentration, enrichment characteristics, source apportionment, chemical speciation and bioavailability. Atmospheric Environment, 99, 257, 2014.

14. HU Y., LIN J., ZHANG S., KONG L., FU H., CHEN J. Identification of the typical metal particles among haze, fog, and clear episodes in the Beijing atmosphere. Science of the Total Environment, 511, 369, 2015.

15. WAN D.J., ZHAN C.L., YANG G.L., LIU X.Q., YANG J.S. Preliminary assessment of health risks of potentially toxic elements in settled dust over Beijing urban area. International Journal of Environmental Research and Public Health, 13 (5), 491, doi:10.3390/ijerph13050491, 2016.

16. BALAKRISHNA G., PERVEZ S., BISHT D.S. Source apportionment of arsenic in atmospheric dust fall out in an urban residential area, Raipur, Central India. Atmospheric Chemistry and Physics, 11 (11), 5141, 2011.

17. PAN S.H., LI J., LIN T., ZHANG G., LI X.D., YIN H. Polycyclic aromatic hydrocarbons on indoor/outdoor glass window surfaces in Guangzhou and Hong Kong, south China. Environmental Pollution, 169, 190, 2012.

18. WAN D.J., HAN Z.X., LIU D.W., YANG J.S. Risk assessments of heavy metals in house dust from a typical 
industrial area in Central China. Human and Ecological Risk Assessment, 22(02), 489, $2016 \mathrm{a}$.

19. MÜLLER G. Index of geoaccumulation in sediments of the Rhine River. GeoJournal, 2, 108, 1969.

20. CNEMC (China National Environmental Monitoring Center). The Background Values of Elements in Chinese Soils. Environment Science Press: Beijing, China, 1990 [In Chinese]

21. CHEN T.B., ZHENG Y.M., CHEN H., ZHENG G.D. Background concentrations of soil heavy metals in Beijing. Environmental Science, 25 (1), 117, 2004 [In Chinese with English abstract].

22. HÅKANSON L. An ecological risk index for aquatic pollution control: a sedimentological approach. Water Research, 14, 975, 1980.

23. LI X.H. Ecological risk assessments and rehabilitation techniques of sediment in antimony mine. Dissertation: Beijing Forestry University, 2013 [In Chinese with English abstract].

24. LU X.W., WU X., WANG Y.W., CHEN H., GAO P.P., FU Y. Risk assessment of toxic metals in street dust from a medium-sized industrial city of China. Ecotoxicology and Environmental Safety, 106, 154, 2014.

25. YAO Q., HAN S.Q., CAI Z.Y. The pollution characteristics and potential ecological risk of heavy metals in $\mathrm{PM}_{2.5}$ during heating season in Tianjin. China. Environmental Science, 33(9), 1596, 2013 [In Chinese with English abstract].

26. YANG Z., GE H., LU W., LONG Y. Assessment of Heavy Metals Contamination in Near-Surface Dust. Polish Journal of Environmental Studies, 24 (4), 1817, 2015.

27. CAO Z., YANG Y., LU J., ZHANG C. Atmospheric particle characterization, distribution, and deposition in Xi'an,
Shaanxi Province, Central China. Environmental Pollution, 159 (2), 577, 2011.

28. BI X., LI Z., SUN G., LIU J., HAN Z. In vitro bioaccessibility of lead in surface dust and implications for human exposure: A comparative study between industrial area and urban district. Journal of Hazardous Materials, 297, 191, 2015.

29. TANNER P.A., MA H.L., YU P.K. Fingerprinting metals in urban street dust of Beijing, Shanghai, and Hong Kong. Environmental Science and Technology, 42 (19), 7111, 2008.

30. FU Z., ZHAI Y., WANG L., ZENG G., LI C., PENG W., LAN Y., LU P. Morphological, geochemical composition and origins of near-surface atmospheric dust in Changsha city of China. Environmental Earth Science, 66 (8), 2207, 2012.

31. HUANG M., WANG W., CHAN C., CHEUNG K., MAN Y., WANG X., WONG M. Contamination and risk assessment (based on bioaccessibility via ingestion and inhalation) of metal(loid)s in outdoor and indoor particles from urban centers of Guangzhou, China. Science of the Total Environment, 479, 117, 2014.

32. Guohua Beijing thermal power plant. Available online: http://baike.baidu.com/link?url=hCuRvD4TperNqxq 8GiDMsuMbVebly-yTj mj5AC7YhvVOKE7CNxY Lz7sfj2WgjXsnLs7HCBY-cb7TBI1PI-yq (accessed on 16 May 2017).

33. WU J. Study on industrial layout planning of Beijing. Beijing City Planning and Construction Review, 6, 54, 2000 [In Chinese].

34. Coal consumption in Beijing reduced to 12 million ton in 2015. Available online: http://news.bjx.com.cn/ html/20160101/697282.shtml (accessed on 16 May 2017). 